\title{
KEMAMPUAN PEMECAHAN MASALAH SISWA PADA POKOK BAHASAN FUNGSI DI KELAS VIII MADRASAH TSANAWIYAH AL- JUNAIDIYAH KAMPUNG LAMO KABUPATEN MANDAILING NATAL
}

\author{
Oleh \\ Nila Sari \\ Ahmad Nizar Rangkuti
}

\begin{abstract}
The background of this research problem is the lack of students' ability to associate the concepts they learn with the problems that exist in their environment. In addition to the lack of maximum problem solving abilities of students who, if seen from the causal elements, one of them is the inappropriate learning method applied by the teacher. The problem discussed in this study is about students' problem solving abilities in the function subject in class VIII Al-Junaidiyah Mandailing Natal District. How is the problem solving ability of students in the function subject in class VIII Al-Junaidiyah Mandailing Natal District ?. Problem solving ability is one of the mathematical abilities that can facilitate students in solving problems in mathematics. This study aims to find out how students' problem solving abilities when faced with math problems students VIII Al-Junaidiyah Mandailing Natal District.

This research is a qualitative research with descriptive approach method. The research subjects were class VIII Al-Junaidiyah Mandailing Natal District as many as 25 students. To obtain this research data using interview instruments and tests. Data analysis used is tabulation with the application of descriptive data.

Based on the results of the study it can be concluded that the problem solving abilities of students on the subject of functions in expressing functions in arrow diagrams are $34.11 \%$, problem solving abilities in expressing functions in cartesius diagrams $21.96 \%$, and problem solving abilities in expressing functions in sequential pairs $16.36 \%$, then the problem solving ability in expressing a notation of a function consisting of 2 items, namely number 4 is $16.82 \%$ and question number 5 is $10.75 \%$. The conclusions found in this study are the lack of student understanding in the concepts of function, which causes a low ability to solve the problem of class VIII students of Al-Junaidiyah, Mandailing Natal District.
\end{abstract}




\begin{abstract}
Abstrak
Latar belakang masalah penelitian ini yaitu kurangnya kemampuan siswa dalam mengaitkan konsep-konsep yang dipelajarinya dengan masalah yang ada dilingkungannya. Selain kurang maksimalnya kemampuan pemecahan masalah siswa yang jika dilihat unsur penyebabnya salah satunya adalah kurang tepatnya metode pembelajaran yang diterapkan oleh guru. Masalah yang dibahas dalam penelitian ini adalah mengenai kemampuan pemecahan masalah siswa dalam pokok bahsan fungsi di kelas VIII Al-Junaidiyah Kabupaten Mandailing Natal. Bagaimana kemampuanpemecahan masalah siswa dalam pokok bahsan fungsi di kelas VIII Al-Junaidiyah Kabupaten Mandailing Natal?. Kemampuan pemecahan Masalah merupakan salah satu kemampuan matematis yang dapat memudahkan siswa dalam memecahakan persoalan-persolan yang ada dalam matematika. Penelitian ini bertujuan untuk mengetahui bagaimana kemampuan pemecahan masalah siswa ketika dihadapkan dengan persoalan matematika siswa VIII AlJunaidiyah Kabupaten Mandailing Natal.

Penelitian ini merupakan penelitian kualitatif dengan metode pendekatandeskriptif.Subjek penelitian adalah siswa kelas VIII Al-Junaidiyah Kabupaten Mandailing Natal sebanyak 25 siswa. Untuk memperoleh data penelitian ini menggunakan instrumen wawancara dan tes.Analisis data yang digunakan adalah tabulasi dengan penerapan data deskriftif.

Berdasarkan hasil penelitian dapat disimpulkan bahwa kemampuan pemecahan masalah siswa pada pokok bahasan fungsi dalam menyatakan fungsi dalam diagram panah 34,11\%, kemampuan pemecahan masalah dalam menyatakan fungsi dalam diagram kartesius $21,96 \%$, dan kemampuan pemecahan masalah masalah dalam menyatakan fungsi dalam himpuanan pasangan berurutan $16,36 \%$, kemudian kemampuan pemecahan masalah dalam menyatakan notasi suatu fungsi yang terdiri dari 2 item soal yaitu nomor soal 4 sebesar $16,82 \%$ dan nomor soal $510,75 \%$. Adapun kesimpulan yang terdapat pada penelitian ini adalah kurangnya pemahaman siswa dalam konsep-konsep fungsi, yang menyebabkan rendahnya kemampuan pemecahanmasalah siswa kelas VIII AlJunaidiyah Kabupaten Mandailing Natal.
\end{abstract}

Kata kunci: kemampuan pemecahan masalah, fungsi, matematika

\title{
A. Pendahuluan
}

Pendidikan merupakan sarana terpenting dalam menciptakan sumber daya manusia yang berkompeten. Pendidikan pada dasarnya adalah usaha sadar untuk menumbuh kembangkan potensi sumber daya manusia, oleh karena itu pendidikan memegang peranan penting dalam meningkatkan sumber daya manusia yang berkualitas dan berdampak pada pembangunan nasional. Sebagaimana dalam Undang-undang RI No.20 Tahun 2003 tentang :

"Pendidikan nasional berfungsi mengembangkan kemampuan dan membentuk watak serta peradaban bangsa yang bermartabat dalam 
rangka mencerdaskan kehidupan bangsa, pendidikan nasional bertujuan untuk berkembangnya potensi peserta didik agar menjadi manusia beriman dan bertaqwa kepada Tuhan Yang Maha Esa, berakhlak mulia,sehat, cakap, kreatif, mandiri dan menjadi warga negara yang demokratis serta bertanggung jawab."1

Dari pernyataan diatas dapatdiartikan bahwa pendidikan merupakan usaha sadar yang diberikan oleh orang dewasa kepada perkembangan anak untuk mencapai kedewasaannya dengan tujuan agar pola pikir dapat berkembang lebih luas dandapat melaksanakan tugas hidupnya sendiri dengan tidak bantuan orang lain.

Pendidikan sangat erat kaitannya dengan belajar. Belajar merupakan suatu perubahan perilaku permanen berdasarkan pengalaman yang diperoleholeh peserta didik. Seseorang dikatakan belajar apabila dalam dirinya terjadi perubahan tingkah lakunya dari tidak tahu menjadi tahu, dari tidak bisa menjadi bisa, dari tidak peduli menjadi peduli. ${ }^{2}$

Dengan demikian dapat disimpulkan bahwa belajar adalah suatu proses latihan menuju perubahan yang akan menghasilkan sesuatu yang dapat diukur dan dapat dipertanggungjawabkan. Perubahan sesuatu yang dapat meningkatkan perbuatan, kemampuan, atau pengertian baru sebagai hasil dari pengalaman. Perubahan dapat menyangkut semua aspek kepribadian individu, yang di dalamnya menyangkut penguasaan,pemahaman, sikap, nilai, motivasi, kebiasaan, minat,apresiasi dalam pembelajaran matematika.

Matematika merupakan ilmu yang dekat dengan kehidupan sehari-hari yang perlu dipahami secara cermat. Dalam mempelajari matematika,proses pembelajarannya sangat berbeda dengan pelajaran yang lain,dikarenakan pada pembelajaran ini sistemnya harus rutun, terurut atau bertangga. Sehingga dalam pembelajarannya siswa sangat diwajibkan memiliki pemahaman yang relevan terhadap kemampuan pemecahan masalah. Mempelajari dan menguasai matematika dibutuhkan suatu ketelitian dalam pemecahan masalah agar mendapatkan hasil yang tepat dan sesuai dengan penalaran yang benar. Kemampuan pemecahan masalah merupakan suatu kesanggupan siswa dalam memaksimalkan pengetahuan, keterampilan dan pemahaman. Dalam mencari solusi dari sebuah permasalahan yang cukup rumit dengan arahan yang terbatas dan solusi ditemukan dapat menghilangkan permasalahan. Sebagaimana Hamdani mengatakan bahwa kemampuan pemecahan masalah adalah suatu cara untuk menyajikan pelajaran dengan mendorong siswa untuk mencari dan

${ }^{1}$ Sisdiknas, Himpunan Perundang-Undangan (Bandung: Fokus Media, 2009), hlm, 3.

${ }^{2}$ Tim-PGSD. Pemantapan Kemampuan Mengajar (PKM) (Universitas terbuka PDGK4209/4SKS/MODULO 1-12 ), hlm. 1.10 
menyelesaikan persoalan dalam rangka pencapaian tujuan pembelajaran. ${ }^{3}$ Dengan adanya kemampuan pemecahan masalah siswa dapat berperan aktif dalam kegiatan belajar mengajar, mencari dan menemukan sendiri informasi atau data untuk diolah menjadi konsep, dan membuat suatu prinsip, teori, atau kesimpulan dari cara penyelesaian masalah.

Dari hasil wawacancara dengan Ibu Eva Yanti, S. Pd, guru matematika yang mengajar di Madrasah Tsanawiyah Al-Junaidiyah Kampung Lamo Kabupaten Mandailing Natal. mengemukakan bahwa pada saat pembelajaran matematika berlangsung kebanyakan siswa kurang mampu menghubungkan antara apa yang mereka pelajari dengan keadaan sekitarnya. Oleh karena itu, seorang guru harus benar-benar bisa untuk menemukan cara yang baik untuk menyampaikan materi yang akan diajarkan sehingga siswa dapat mengingat lebih lama tentang konsep yang telah diajarkan. Hal yang paling utama dalam pemecahan masalah yang dihadapi oleh siswa yaitu mampu menggunakan teknik pembelajaran yang berkaitan dengan pemecahan masalah yang dihadapi oleh siswa itu sendiri.

Rendahnya kemampuan siswa dalam pemecahan masalah disebabkan beberapa faktor-faktor yaitu: 1) kurangnya pendekatan pembelajaran yang dilakukan guru terhadap siswa terutama dalam pengembangan kemampuan pemecahan masalah yang dihadapi siswa. 2) Teknik pembelajaran yang dilakukan guru kurang bervariasi,dan guru lebih mendominasi dalam penyajian materi sehingga membuat siswa menjadi pasif. 3) Selain itu siswa beranggap bahwa matematika itu sulit. ini dikarenakan hitung menghitung yang sulit diselesaikan dan harus menghapal rumus-rumus. dan dimana letak daya ingat yang diperlukan serta analisis yang dalam penggunaannya.

Hal lain yang mengakibatkan hasil belajar siswa masih rendah dalam menyelesaikan pokok bahasan fungsi. Selain itu dituntut untuk menyelesaikan masalah yang dihadapi oleh siswa, siswa itu sendiri dan dituntut juga untuk memiliki kemampuan yang lain.kemampuan itu di antaranya menelaah maksud dari suatu kalimat. kemampuan mengubah kalimat bahasa menjadi bentuk persamaan bentuk matematika dan memilih metode yang sesuai dalam menyelesaikan soal yang diberikan terutama pokok bahasan fungsi.

Dalam pokok bahasan fungsi ini ada beberapa materi yang harus diketahui salah satu menyatakan suatu fungsi dengan berbagai cara yang dilakukan dan menentukan notasi suatu fungsi. Materi tersebut akan mudah dikuasai jika siswa memahami cara penyelesaian masalah dengan menemukan konsepnya sendiri.

Untuk melihat kemampuan pemahaman belajar siswa pada pemecahan masalah matematika pokok bahasan fungsi,diperlukan penerapan teknik pembelajaran yang tepat.pemahaman maksud ini adalah pemahaman siswa terhadap kemampuan pemecahan masalah yang menjadi dasar kualitatif .

Dengan adanya Proses pemecahan masalah dapat menjadikan siswa berperan aktif dalam kegiatan brelajar mengajar, mencari dan menemukan sendiri informasi/data untuk diolah menjadi konsep dan membuat suatu prinsip

${ }^{3}$ Hamdani, Strategi Belajar Mengajar (Bandung: CV. Pustaka Setia. 2011), hlm. 84. 
dari cara penyelesaian masalah.untuk meningkatan kemampuan Pemahaman belajar siswa pada pemecahan masalah matematika pada pokok bahasan fungsi, diperlukan penerapan teknik pembelajaran yang tepat. Pemahaman yang dimaksud ini adalah pemahaman siswa terhadap kemampuan pemecahan masalah yang menjadi dasar kualitatif dimana fakta-fakta atau informasi saling berkaitan dengan kemampuan untuk menggunakan pengetahuan tersebut dalam situasi baru (pengaplikasian di dalam kehidupan sehari-hari).

Selain itu akan terjadi komunikasi antara guru dan siswa,hal ini akan menyebabkan siswa lebih berperan aktif dalam pembelajaran matematika pada pokok bahasan fungsi. Berdasarkan hal tersebut peneliti tertarik untuk melakukan penelitian untuk melihat kemampuan pemecahan masalah siswa dalam pokok bahasan fungsi dengan judul "Kemampuan Pemecahan Masalah Siswa Pada Pokok Bahasan Fungsi di kelas VIII Madrasah Tsanawiyah Kampung Lamo Kabupaten Mandailing Natal.”

\section{B. METODOLOGI PENELITIAN}

\section{Lokasi dan Waktu Penelitian}

Lokasi penelitian ini dilaksanakan di Madrasah Tsanawiyah AlJunaidiyah Kampung Lamo Kabupaten Mandailing Natal pada tahun ajaran 2016/2017 pada materi fungsi.

\section{Jenis Penelitian}

Penelitian ini merupakan penelitian kualitatif dengan metode pendekatan deskriptif.

\section{Subjek Penelitian}

Adapun yang menjadi subjek penelitian adalah siswa kelas VIII ALJunaidiyah Kampung Lamo yang berjumlah 25 orang yang terdiri 10 orang siswa dan 15 orang siswi.

\section{Instrumen Pengumpulan Data}

Instrumen pengumpulan data yang digunakan dalam penelitian ini adalah wawancara dan tes yang terdiri dari 5 soal.

\section{Teknik Analisis Data}

Analisis Data dilaksanakan dengan menggunakan analisis dekskriptif. Yaitu Analasisis yang tidak menguji hipotesis tertentu, tetapi menggambarkan "apa adanya" dengan suatu variabel. Semua data yang dikumpulkan akan di sampaikan dengan menggunakan metode induktif.

Tahap-tahap yang dilakukan oleh peneliti dalam keabsahan data terhadap apa yang harus diteliti, yaitu: 1) Persiapan dan 2) Tabulasi. 


\section{Teknik Pengecekan Keabsahan Data}

Langkah yang ditempuh oleh peneliti dalam keabsahan data terhadap apa yang akan diteliti adalah kredibilitas terhadap data yang dikumpulkan sewaktu melakukan penelitian dengan teknik pemeriksaan triangulasi terhadap data tersebut. Hal ini sejalan dengan apa yang dikatakan oleh Ahmad Nizar Rangkuti bahwa, "Triangulasi data adalah suatu pendekatan analisis data yang mensintesa data dari berbagai sumber, dimana triangulasi merupakan pencarian dengan cepat pengujian terhadap data yang sudah ada dalam memperkuat tafsiran dan meningkatkan kebijakan serta program yang berbasis pada bukti yang telah tersedia". ${ }^{4}$ Selain itu juga menyatakan bahwa " Triangulasi data mencakup penggunaan sumber data/informasi berbeda, dengan kunci mengelompokkan sumber data dari obyek penelitian yang akan diteliti kemudian data yang dikumpulkan dibandingkan satu sama lainnya". ${ }^{5}$ Dari pernyataan ini maka peneliti menganggap bahwa teknik keabsahan data dengan metode triangulasi data merupakan salah satu teknik didalam mengolah data terhadap apa yang menjadi bahan untuk mengalisa data yang telah terkumpul sewaktu mengadakan penelitian terhadap judul yang diangkat oleh peneliti sendiri.

\section{Hasil dan Pembahasan Penelitian}

\section{Hasil tes}

Tes yang diujikan kepada peserta didik menggunakan kriteria dalam bentuk skor, ini akan menggambarkan hasil perolehan peserta didik dalam menyelesaikan soal pokok bahasan fungsi. Hasil tes pokok bahasan fungsi kelas VIII Madrasah Tsanawiyah Al-junaidiyah Kampung Lamo kabupaten Mandailing Natal diperoleh data yaitu: peserta didik yang memperoleh hasil yang mencapai kriteria ketuntasan minimal (KKM) sebanyak 7 peserta didik, sedangkan peserta didik yang tidak memperoleh hasill yang memcapaikriteria ketuntasan minimal (KKM) sebanyak 18 orang peserta didik. Selengkapnya mengenai hasil tes tentang kemampuan siswa dalam menyelesaikan soal pokok bahasan Fungsi dijabarkan sebagai berikut:

\section{a. Kemampuan Siswa Dalam Menyatakan Fungsi Dengan Diagram Panah}

Soal yang menyatakan fungsi dengan diagram panah terdiri dari satu soal yaitu soal nomor 1. Berdasarkan hasil jawaban siswa pada

\footnotetext{
${ }^{4}$ Ahmad Nizar Rangkuti, Metode Penelitian Pendidikan ( Bandung: Cipta Pustaka Media, 2015 ), hlm. 146.
}

${ }^{5}$ Ibid., hlm. 148. 
umumnya mendekati sempurna menjawab soal nomor 1 . Ini terlihat dari banyaknya siswa yang memperoleh skor yang yang tinggi. Skor 20 diperoleh sebanyak 8 orang siswa, yang berarti bahwa siswa dapat menyelesaikan soal dengan tepat dan benar baik jalan penyelesaian dan jawaban akhirnya atau dapat dikatakan bahwa analisa jawaban benar sesuai dengan pemecahan masalah. Sebanyak 9 siswa memperoleh skor 15, yang berarti bahwa siswa memiliki kesalahan satu langkah. Sebanyak 7 siswa memperoleh skor 15, ini artinya siswa melakukan kesalahan sebanyak 2 langkah. Dan 1 siswa memperoleh skor 0, artinya melakukan kesalahan dikeseluruhan langkah-langkah penyelesaian.

Dari hal di atas dapat dilihat bahwa untuk soal nomor 1 siswa dapat menguasai materi yang diajarkan dan memiliki kemampuan pemecahan masalah yang baik. Untuk persentase pencapaian siswa dalam menyelesaiakan soal dengan pemecahan masalah yaitu:

$$
\begin{aligned}
\text { Persentase } & =\frac{\text { jumlah skor penjumlahan }}{\text { total skor keseluruhan }} \times 100 \% \\
& =\frac{365}{1070} \times 100 \%=34,11 \%
\end{aligned}
$$

\section{b. Kemampuan Siswa Dalam Menyatakan Fungsi Dengan Diagram Kartesius}

Soal yang menyatakan fungsi dengan diagram kartesius terdiri dari satu soal yaitu soal nomor 2. Berdasarkan hasil jawaban siswa pada umumnya memenuhi langkah-langkah pemecahan masalah dalam menjawab soal. Ini terlihat dari banyaknya siswa yang memperoleh skor yang yang tinggi. Skor 20 diperoleh sebanyak 3 orang siswa, yang berarti bahwa siswa dapat menyelesaikan soal dengan tepat dan benar baik jalan penyelesaian dan jawaban akhirnya atau dapat dikatakan bahwa analisa jawaban benar sesuai dengan pemecahan masalah. Sebanyak 3 siswa memperoleh skor 15, yang berarti bahwa siswa memiliki kesalahan satu langkah. Sebanyak 9 siswa memperoleh skor 10, ini artinya siswa melakukan kesalahan sebanyak 2 langkah. Skor 5 sebanyak 8 siswa. Dan 1 siswa memperoleh skor 0, artinya melakukan kesalahan dikeseluruhan langkah-langkah penyelesaian.

Dari hal di atas dapat dilihat bahwa untuk soal nomor 2 siswa dapat menguasai materi yang diajarkan dan memiliki kemampuan pemecahan masalah yang lumayan baik. Untuk persentase pencapaian siswa dalam menyelesaiakan soal dengan pemecahan masalah yaitu:

$$
\begin{aligned}
\text { Persentase } & =\frac{\text { jumlah skor penjumlahan }}{\text { total skor keseluruhan }} \times 100 \% \\
& =\frac{235}{1070} \times 100 \%=21,96 \%
\end{aligned}
$$




\section{c. Kemampuan Siswa Dalam Menyatakan Fungsi Dengan Himpunan Pasangan Berurutan}

Soal yang menyatakan fungsi dengan himpunana pasangan berurutan terdiri dari satu soal yaitu soal nomor 3. Berdasarkan hasil jawaban siswa pada umumnya lumayan baik. Ini terlihat dari banyaknya siswa yang memperoleh skor yang yang tinggi. Skor 20 diperoleh sebanyak 2 orang siswa, yang berarti bahwa siswa dapat menyelesaikan soal dengan tepat dan benar baik jalan penyelesaian dan jawaban akhirnya atau dapat dikatakan bahwa analisa jawaban benar sesuai dengan pemecahan masalah. Sebanyak 3 siswa memperoleh skor 15, yang berarti bahwa siswa memiliki kesalahan satu langkah. Sebanyak 6 siswa memperoleh skor 10, ini artinya siswa melakukan kesalahan sebanyak 2 langkah. Skor 5 sebanyak 6 siswa. Dan sebanyak 8 siswa memperoleh skor 0 , artinya melakukan kesalahan dikeseluruhan langkah-langkah penyelesaian.

Dari hal di atas dapat dilihat bahwa untuk soal nomor 3 siswa kurang dapat menguasai materi yang diajarkan dan kemampuan pemecahan masalah yang kurang. Siswa dalam menyelesaikan soal nomor 3 mengalami kebinungan dalam menyelesaiakan hal ini terlihat siswa salah dalam langkah-langkah dan kurang memahami apa yang ditujukan oleh soal. Soal nomor 3 ditujukan dalam menyatakan fungsi kedalam himpunana pasangan berurutan, namun siswa menyelesaikan ke dalam diagram panah.Untuk persentase pencapaian siswa dalam menyelesaiakan soal dengan pemecahan masalah yaitu:

$$
\begin{aligned}
\text { Persentase } & =\frac{\text { jumlah skor penjumlahan }}{\text { total skor keseluruhan }} \times 100 \% \\
& =\frac{175}{1070} \times 100 \%=16,36 \%
\end{aligned}
$$

Dari hasil analisis lembar jawaban siswa diatas dapat diketahui bahwa persentasi kemampuan siswa pada kemampuan pemecahan masalah pada pokok bahasan fungsi yang terdiri dari 5 soal. Dan secara detailnya dapat dilihat pada tabel.

Tabel 1. Persentasi kemampuan siswa dalam menjawab soal

\begin{tabular}{|c|c|}
\hline Soal & Tingkat Kemampuan Siswa \\
\hline 1 & $34,11 \%$ \\
\hline 2 & $21,96 \%$ \\
\hline 3 & $16,36 \%$ \\
\hline 4 & $16,82 \%$ \\
\hline 5 & $10,75 \%$ \\
\hline
\end{tabular}




\section{Hasil wawancara}

Berikut hasil wawancara yang dilakukan dengan guru dan siswa:

a. Hasil wawancara dengan guru ${ }^{6}$

Hasil wawancara yang diperoleh dengan guru menyatakan bahwa siswa kelas VIII Madrasah Tsanawiyah Kampung Lamo merupakan siswa yang kooperatif, mereka mengikuti apa yang dikatakan oleh guru. Metode yang sering digunakan guru adalah konvensional. Dalam pembelajaran Biasanya guru menerangkan kembali apa materi yang telah diberikan. Untuk interpretasinya diadakan latihan ulangan menjadikan siswa mengetahui titik kelemahannya pada konsep pemecahan masalah.

Ketika siswa menemukan masalah dalam menyelesaikan materi maka sebagai seorang guru harus memberikan materi bahan ajar yang sesuai dengan kemampuan siswa, serta materi yang diajarkan harus dimengerti dan dipahami oleh setiap siswa.

Kemampuan yang dimiliki oleh setiap siswa itu berbeda-beda terutama dalam hal pemecahan masalah yang sering di temui pada pokok bahasan fungsi.

Siswa merasa kesulitan apabila materi yang diajarkan mulai banyak mengaitkan antara konsep satu dengan lain dan apabila soal yang dibuat soal berbeda dengan yang buat contoh pada penjelasan. Guru menyatakan bahwa dalam menotasikan fungsi siswa merasa sulit sebab dihadapi pada aljabar yang rumit, pelambangan pernyataan dan lain sebagainya.

b. Hasil wawancara dengan siswa

Wawancara dilakukan dengan siswa. Adapun hasil wawancara diuraikan sebagai berikut:

Nuraminah Rangkuti mengemukakan bahwa ia mengalami kendala dalam notasi fungsi,sebagaiman yang dinyatakannya dalam wawancara:

"Saya merasa sering menemukan kendala pada penotasian fungsi. Dalam langkah-langkah penyelesaiannya soal saya dapat menyelesaikannya walaupun tidak semuanya. Permasalahan yang biasa saya hadapi adalah kurangnya akan pengubahan konsep cerita pada pengubahannya terhadap bilangan matematikanya. Yang menjadi

\footnotetext{
${ }^{6}$ wawancara dengan Ibu guru mata pelajaran matematika kelas VIII
} Madrasah Tsanawiyah Kampung Lamo, 11 November 2016. 
permasalahan utama bagi saya adalah pelambangan dalam fungsi. $^{7}$

Saipul Anwar menyatakan jika ia sering mengalami kendala dalam soal berbentuk cerita sebagaimana dinyatakannya:

"Saya merasa sering tidak dapat menyelesaikannya persoalan yang benbentuk soal cerita. Hal ini seperti kurangnya kemampuan saya dalam menjawab soal cerita yang ditujukan dalam himpunan pasangan beurutan. Yang menjadi permasalahan utama bagi saya soal cerita."

Rayhan Afriani Rkt menyatakan jika ia sering mengalami kendalam dalam langkah-langkah penyelesaian sebagaimana dinyatakannya:

"Saya mengalami kendala pada penotasian fungsi. Saya tidak dapat menyelesaikannya persoalan yang menyangkut notasi fungsi. Permasalahan yang biasa saya hadapi adalah kurangnya akan pengubahan konsep cerita pada notasi pokok bahasan fungsi. Yang menjadi permasalahan utama bagi saya adalah notasi fungsi dalam soal cerita."9

Dari wawancara diatas dapat dikatakan bahwa siswa menemukan atau mengalami kendala pada pokok bahasan notasi fungsi. Siswa mengalami Permasalahan pada pengubahan konsep cerita pada notasi pokok bahasan fungsi.

\section{Analisis Hasil Penelitian}

Kemampuan siswa dalam belajar matematika merupakan suatu kemampuan siswa dalam menyelesaikan atau memecahkan masalah matematika yang dihadapinya. Kemampuan itu salah satunya ditujukan untuk menyelesaikan pokok bahsan fungsi. Siswa akan lebih mudah belajar apabila ada dasar pengetahuan dalam suatu bidaang ilmu sebelumnya. Karena itu untuk mempelajari suatu materi matematika yang baru terutama pokok bahasan fungsi, pengalaman belajar yang lalu dari siswa merupakan hal yang mempengaruhi proses belajar mengajar materi matematika.

${ }^{7}$ wawancaradengan Nuraminah Rangkuti, siswa kelas VIII Madrasah Tsanawiyah Kampung Lamo, 12 November 2016.

${ }^{8}$ wawancara dengan Saipul Anwar, siswa kelas VIII Madrasah Tsanawiyah Kampung Lamo, 12 November 2016.

${ }^{9}$ wawancara dengan Rayhan Afriani Rkt, siswa kelas VIIIMadrasah Tsanawiyah Kampung Lamo, 12 Novemberr 2016. 
Kemampuan dasar yang harus dimiliki setiap siswa adalah suatu kemampuan yang harus atau wajib dimiliki yang merupakan prasyarat sebelum mempelajari suatu materi baru, apabila kemampuan itu tidak dikuasai maka tujuan pembelajaran yang diharapkan tidak mungkin tercapai. Hal ini terlihat dari hasil ketuntasan belajar siswa pada pokok bahasan fungsi sangat rendah dengan siswa yang tuntas sebanyak 7 siswa dari 25 keseluruhan siswa yang diberikan test mengenai fungsi.

Jika dilihat dari pakta dilapangan ditemukan bahwa ketika dalam menjelaskan materi guru masih menggunakan metode pembelajaran konvensional, sehingga murid kurang aktif dalam pembelajaran padahal seharunya siswa harus aktif dalam pembelajaran. Guru kurang memperhatikan dengan betul bagaimana pemahaman siswa terhadap materi. Padahal seharusnya pemahaman siswa itu sangatlah penting khususnya materi fungsi, dimana materi ini sangat banyak berkaitan dalam matematika. Dan dengan ketidak pahaman siswa maka akan mempengaruhi hasil belajar siswa..

Demikian juga halnya untuk mempermudah siswa, kemampuan pemecahan masalah yang ditemui dalam menyelesaikan soal fungsi diperlukan adanya penguasaan sifat-sifat atau konsep-konsep yang ada pada notasi fungsi. Dari lima item tes yang diberikan kepada siswa didapat hasil pada notasi fungsi dimana kemampuan pemecahan masalah oleh siswa sangat rendah. Hal ini dikarenakan notasi fungsi berkaitan dengan melambangkan suatu penyataan dimana memerlukan analisis dan konsep yang sangat kuat. Selain itu kebanyakan siswa kurang teliti dan terlalu terburu-buru dalam menyelesaian soal, sehingga menyebabkan hasil yang tidak maksimal dan tidak sesuai dengan langkah-langkah penyelesaian soal pemecahan masalah.

Namun di sisi lain jika ditinjau dari materi menyatakan fungsi dengan diagram baik itu diagram panah dan kartesius, bisa dikatakan siswa memiliki kemampuan pemecahan masalah yang baik dalam soal ini terlihat dari banyaknya siswa yang memperoleh nilai yang baik.

Dari uraian di atas dapat disimpulkan bahwa dalam hal penyelesaian masalah pokok bahasan fungsi ditemukan masalah yang paling mendasar bagi setiap siswa pada umumnya adalah notasi fungsi dan kurangnya penguasaan materi. Di sisi lain pengaplikasian dari satu konsep ke konsep lainnya belum dipahami oleh siswa contohnya notasi fungsi yang dikaitkan dengan pencarian keliling dari suatu bidang. Sebagian siswa lagi ada yang lupa akan cara dan langkah dalam menyatakan fungsi dalam himpunan pasangan berurutan. Adanya kemampuan pemecahan masalah dalam belajar matematika khususnya pokok bahasan fungsi dapat meningkatkan prestasi siswa dalam menyelesaikan soal-soal materi fungsi.

\section{KETERBATASAN PENELITIAN}

Pelaksanaan penelitian ini dilakukan dengan langkah-langkah yang disusun sedemikian rupa agar hasil yang diperoleh sebaik mungkin. Namun, untuk mendapatkan hasil yang sempurna sangatlah sulit, sebab dalam pelaksanaan penelitian ini terdapat beberapa keterbatasan.

Diantara keterbatasan yang dihadapi penulis selama melaksanakan penelitian dan penyusunan skripsi ini adalah dari segi teknik pelaksanaan 
penelitian, terutama dalam pengawasan saat siswa menjawab soal penulis kurang dapat menguasai keadaan siswa sehingga menimbulkan kesempatan bagi siswa dalam menjawab soal bukan berdasarkan kemampuannya sendiri. Hal ini dapat terjadi karena penulis tidak dapat melakukan control pengawasan yang lebih baik dan tidak dapat melihat apakah kondisi siswa benar-benar baik dalam memberikan jawaban atas butir-butir soal yang diujikan, sehingga terkadang jawaban dari siswa dapat bersifat terkaan sehingga mempengaruhi validitas data yang diperoleh.

Keterbatasan-keterbatasan yang disebutkan diatas berpengaruh terhadap hasil peneliti dan penyusunan skripsi ini, dengan segala upaya yang dan kerja keras yang dilakukan yaitu peneleliti melakukan penelitian ini dengan naik angkot sekitar $2 \mathrm{~km}$, dan berjalan kaki sekitar 150 meter menuju yayasan Al-Junaidiyah Kampung Lamo bersama teman yang Rizki Adelina Rangkuti yang peneliti ajak untuk menemani peneliti untuk meneliti.selain itu peneliti menghadapi hambatan-hambatan dalam sosialisasi dengan guru yaitu sulitnya mendapatkan informasi yang dibutuhkan sehingga peneliti harus melakukan pendekatan yang ekstra. Meskipun penulis menemui hambatan dalam pelaksanaan penelitian, penulis berusaha sekuat tenaga agar keterbatasan yang dihadapi tidak mengurangi makna penelitian ini. Akhirnya dengan segala upaya, kerja keras dan bantuan semua pihak skripsi ini dapat diselesaikan.

\section{Penutup}

\section{Simpulan}

Kemampuan pemecahan masalah siswa pada pokok bahasan fungsi dalam menyatakan fungsi dalam diagram panah 34,11\%, kemampuan pemecahan masalah dalam menyatakan fungsi dalam diagram kartesius $21,96 \%$, dan kemampuan pemecahan masalah masalah dalam menyatakan fungsi dalam himpunan pasangan berurutan 16,36\%, kemudian kemampuan pemecahan masalah dalam menyatakan notasi suatu fungsi yang terdiri dari 2 item soal yaitu nomor soal 4 sebesar $16,82 \%$ dan nomor soal $510,75 \%$. Adapun kesimpulan yang terdapat pada penelitian ini adalah kurangnya pemahaman siswa dalam konsep-konsep fungsi, yang menyebabkan rendahnya kemampuan pemecahan masalah siswa kelas VIII Al-Junaidiyah Kabupaten Mandailing Natal.

Berdasarkan analisis yang dialakukan dapat disimpulkan bahwa dalam hal penyelesaian masalah pokok bahasan fungsi ditemukan masalah yang paling mendasar bagi setiap siswa pada umumnya adalah notasi fungsi dan kurangnya penguasaan materi. Di sisi lain pengaplikasian dari satu konsep ke konsep lainnya belum dipahami oleh siswa contohnya notasi fungsi yang dikaitkan dengan pencarian keliling dari suatu bidang. Sebagian siswa lagi ada yang lupa akan cara dan langkah dalam menyatakan fungsi dalam himpunan pasangan berurutan. 


\section{Saran}

Beberapa saran sebagai bahan pertimbangan untuk perbaikan ke depan sebagai berikut:

1. Kepada kepala sekolah agar memotivasi guru dalam melaksanakan kegiatan proses belajar mengajar matematika.

2. Kepada guru bidang studi matematika agar kiranya semaksimal mungkin untuk melakukan proses pembelajaran matematika yang berkaitan dengan memberikan konsep-konsep matematika sehingga dapat meningkatkan pemahaman dan kemampuan siswa dalam menyelesaikan soal matematika terutama materi pokok bahasan fungsi.

3. Kepada siswa hendaknya meningkatkan konsep kemampuan pemecahan masalah dalam memahami setiap permasalahan yang dihadapi terutama di bidang matematika dan mata pelajaran lainnya. Agar hasil belajar dapat meningkat sebab dengan adanya kemampuan pemecahan masalah setiap persoalan yang dihadapi dapat dicari jalan keluarnya.

4. Kepada peneliti lain, temuan penelitian ini merupakan bahan kajian yang dapat dikembangkan lebih luas dan mendalam lagi dengan menambah sebagai bahan referensi tambahan.

\section{DAFTAR PUSTAKA}

Nasution S. Berbagai Pendekatan dalam Proses Belajar dan Mengajar, Jakarta : Bumi Aksara,1982.

Dinn Wahudin, dkk. Pengantar Pendidikan. Universitas terbuka Mkdk 4001/3sks/Modulu, 2007.

Hamdani, Strategi Belajar Mengajar. Bandung: CV.Pustaka Setia. 2011.

Hamzih B.Uno, Model Pembelajaran Menciptakan Pross Belajar Mengajar yang Kreatifdan Epektif, jakarta: Bumi Aksara, 2008.

Harun Rasyid Mansur, Penilaian Hasil Belajar. Bandung Wacana Prima, 2007.

Hasan Alwi, dkk, Kamus Besar Bahasa Indonesia Jakart: Balai Pustaka 2001.

Joko Sugyono, Metodologi Penelitian dalam Teori dan Praktek. Jakarta: Rineka Cipta, 2001.

Lexy,J.Moleong. Metodologi Penelitian Kualitatif, Bandung: PT. Remaja Rosda karya, 2013. 
Makmun Khairan, Psikologi Belajar . Yogyakarta:Aswaja Pressindo 2013.

Ramayulis, Metodologi Pendidikan Agama Islam, Jakarta:Kalah Mulia, 2010.

Rangkuti Ahmad Nizar, Metode Penelitian Pendidikan. Bandung: Cipta Pustaka Media, 2015.

Rusman, Model-model Pembelajaran Mengembangkan Profesionalisme Guru . Jakarta: Rajawali Pers, 2011.

S. Margono, Metodologi Penelitian Pendidikan. Jakarta: Rineka Cipta, 2004

Suharsimi Arikunto, Manajemen Penelitian . Jakarta: Rineka Cipta,1995.

Sukino dan Wilson Simangunsung, Matematika untuk SMP Kelas VIII. Erlangga Gelora Aksara Prtama, 2006.

Sukirman,dkk. Matematika. Universitas Terbuka PDGK4203/3SKS/MODUL.

Trianto, Mendesain Model Pembelajaran Inovatif Progresif Konsep Landasan,dan Implementasinya pada Kurikulum Tingkat Satuan Pendidikan (KTSP) . Jakarta : Kencana, 2009. 